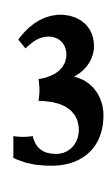

\title{
ATTITUDES AND CULTURAL STEREOTYPES OF FUTURE TEACHERS TOWARDS IMMIGRANT STUDENTS IN SPAIN
}

\section{(ACTITUDES Y ESTEREOTIPOS CULTURALES DE LOS FUTUROS MAESTROS HACIA EL ALUMNADO INMIGRANTE EN ESPAÑA)}

Dimitrinka G. Níkleva

Ana M. Rico-Martín

Universidad de Granada

DOI: $10.5944 / e d u c X X 1.17491$

\section{Cómo referenciar este artículo/How to reference this article:}

Níkleva, D.G. \& Rico-Martín, A.M. (2017). Attitudes and cultural stereotypes of future teachers towards immigrant students in Spain. [Actitudes y estereotipos culturales de los futuros maestros hacia el alumnado inmigrante en España]. Educación XX1, 20(1), 57-73, doi: 10.5944/educXX1.17491

\section{ABSTRACT}

The purpose of this study is to find the predominant attitudes and cultural stereotypes towards immigrants in Spain among future teachers, and the sources of information that influence them the most. The mental associations caused by the words foreigner and immigrant, and the ranking of the immigrant nationalities - according to positive or negative attitudes towards them - are studied. In order to do this, stereotype functions are explained and an opinion survey of 151 students of the Primary Education degree at the University of Granada is analyzed. The research instrument is a 41 -item questionnaire with closed- and open-ended questions and it combines dichotomous and open questions with Likert scale questions. Data analysis was done with the SPSS 17.0 statistics software (Statistical Product and Service Solutions). The variables were subjected to descriptive analysis to obtain the frequency and percentages of the answers. We used inferential analysis to study the relationships between qualitative variables.

Considering that stereotypes and prejudices hamper coexistence and are consolidated through a lack of intergroup contact —and therefore through a lack of knowledge of the Other- it becomes important to support these contacts in 
the educational sphere to improve attitudes towards immigrants and reduce xenophobia.

The word immigrant is associated in the first place with poverty, need and an illegal stay. The word foreigner is attributed to a person with money who resides legally in Spain for pleasure.

The authors consider that the results of this study will be useful in diagnosing the current situation and later designing pedagogical interventions directed at increasing the acceptance of inclusive education principles among future teachers.

This study is part of an I+D project, titled "The training of teachers of Spanish for immigrants in different educational contexts” (code EDU2013-43868-P).

\section{KEY WORDS}

Ethnic stereotypes; social attitudes; migrant education; preservice teachers; Inclusive education.

\section{RESUMEN}

Este estudio pretende detectar las actitudes y estereotipos culturales predominantes entre los futuros maestros hacia los inmigrantes en España y las fuentes de información que influyen en mayor medida. Se estudian las asociaciones que provocan las palabras extranjero e inmigrante, igual que la posición de las nacionalidades de los inmigrantes, según las actitudes positivas o negativas hacia ellas.

Se explican las funciones de los estereotipos y se analiza un cuestionario de opinión de 151 alumnos en el Grado de Educación Primaria en la Universidad de Granada. El instrumento de investigación es un cuestionario compuesto por 41 ítems de preguntas cerradas y abiertas que combina algunas preguntas dicotómicas y abiertas con otras de escala Likert.

El análisis de datos se realizó con el programa estadístico SPSS 17. Se aplicó el análisis descriptivo de las variables para obtener la frecuencia y los porcentajes de las respuestas. Para el estudio de la relación entre variables cualitativas se ha empleado el análisis inferencial.

Teniendo en cuenta que los estereotipos y los prejuicios dificultan la convivencia y además, se consolidan por la falta de contacto intergrupal y, por consiguiente, desconocimiento del Otro, resulta importante facilitar estos contactos en el espacio educativo para mejorar las actitudes hacia los inmigrantes y reducir la xenofobia. 
La palabra inmigrante se asocia en primer lugar a la pobreza, la necesidad y a una estancia ilegal, mientras que la palabra extranjero se atribuye a una persona adinerada que reside en España legalmente por placer.

Las autoras consideran que los resultados servirán para obtener un diagnóstico de la situación actual y diseñar una intervención pedagógica destinada a mejorar la aceptación de los principios de la educación inclusiva entre los futuros maestros.

El presente estudio se realizó en el marco de un proyecto $\mathrm{I}+\mathrm{D}$, titulado $\mathrm{La}$ formación de los docentes de español para inmigrantes en diferentes contextos educativos (código EDU2013-43868-P).

\section{PALABRAS CLAVE}

Estereotipos culturales; actitudes hacia los inmigrantes; maestros; alumnos inmigrantes; educación inclusiva.

\section{INTRODUCTION}

To confront the immigration phenomenon - which is continuously increasing and involves linguistic, cultural, ethnic and religious diversitythe Spanish education system has created a set of fundamental intercultural education measures distributed along three axes: acceptance, acquisition of Spanish as a vehicular language, and the upholding of the original culture. According to current policies, all these measures are located in the framework of inclusive education, although in practice both inclusive and segregationist approaches are applied.

With respect to all of these problems, we consider that future teachers should receive specific training about intercultural education in order to teach immigrant students professionally in the future. A starting point is to study the attitudes of future teachers toward immigrants and their initial opinion as to the approach they might take in order to integrate immigrant students and avoid racist attitudes in the classroom.

\section{THEORETICAL FRAMEWORK AND PREVIOUS STUDIES}

\section{Statistical data and attitudes towards immigrants in Spain}

Before initiating the study, we consider it appropriate to offer several statistical data about Spain's population and the number of immigrants in order to contextualize this research better and show its present-day validity and relevance. 
In 2012, Spain's population stood at more than 47 million. According to data from the National Statistics Institute in Spain (Instituto Nacional de Estadística, 2012), as of 2010, 40,416,850 inhabitants had been born in Spain and 6.6 million abroad. Of the latter, 5,747,734 were non-Spanish nationals, and of these. Romanians made up the largest group with 784,834 inhabitants, Moroccans the second with 760,238, and Chinese the eleventh with 154,119.

Concerning the evolution of the foreign student population in Spain, Figure 1 presents data from the Ministry of Education and Science in Spain (Instituto de Formación de Profesorado, Investigación e Innovación Educativa, IFIIE, 2012) for the 2000 to 2011 period.

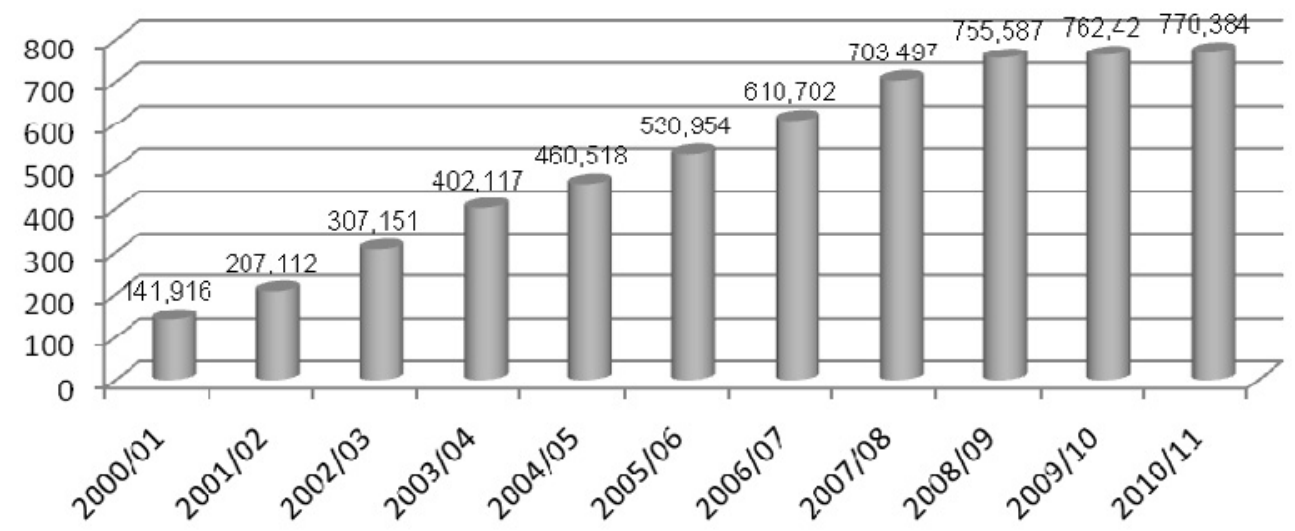

Figure 1. Foreign student population evolution in Spain

We observe a continuous increase in foreign student population: from 141,916 in $2000 / 2001$ to 770,384 in $2010 / 2011$.

It is important for our study to learn the predominant attitudes in Spanish society towards immigrants before concentrating on the attitudes of future teachers. From among the previous studies, we have decided to highlight Checa and Arjona (2011), which shows an increasing anti-immigration sentiment in Spain in recent years coupled with xenophobia and immigrant rejection. Checa and Arjona (2011) is based on data from a national survey on opinions and attitudes towards immigration done annually by Sociological, Economical and Political Analyses in Spain [Análisis Sociológicos, Económicos y Políticos, ASEP] and the analysis of immigrant related news published in 1997/1998 and in 2006/2007 by the two largest circulation newspapers in Spain: El País and El Mundo. 
In 2010 in Spain, immigration was considered the fourth most serious problem, after unemployment, economic difficulties and political parties. The media have a critical role in molding opinions and attitudes and they can become a source of prejudice and stereotypes that lead to racism. The longitudinal study cited indicates a progressive increase in anti-immigrant sentiment. Foreigners are identified as enemies of cultural identity and sources of unemployment, criminality, and wage reduction. However, we would like to highlight another result from this study: having a long conversation with a foreigner reduces the negative perception of the exogroup, and intense intergroup contact reduces xenophobia (Briones, Tabernero \& Arenas, 2011; Checa \& Arjona, 2011; García \& Saura, 2008). For the 1997/1998 period, the largest anti-immigrant sentiment was associated with the variables of being of older age, having a right-wing ideology, and less education, being married, being male and being unemployed. In 2006/2007, being male and unemployed are the most relevant demographic variables while levels of education and income lose their prediction capability. It needs nothing that the latter two-year period has the lowest recorded unemployment rate of the whole period under analysis.

In general, numerous studies have proven that xenophobia increases in times of crisis. The sense of threat among Spaniards increases with the competition for employment and several resources and benefits such as housing, education or health. On the other hand, a point is reached at which some groups are conceptualized as culturally incompatible. Cultural differences are exaggerated and prejudices and stereotypes are upheld. Culture is considered as something inherited or, in other words, "there is a genealogic, and therefore racial, concept of culture and its transmission" (Todd, 1996, p. 343).

Llorent (2012) has carried out a similar study (between January 2009 and June 2010) of the digital edition of these two newspapers and their importance in forming positive or negative attitudes about immigration. In his analysis, Llorent poses the following question: What vision of the current coexistence between the immigrant collective and the receiving society do these newspapers offer? (Llorent, 2012, p. 143). For "El Mundo," the results are as follows: positive $(45,1 \%)$, negative $(33,8 \%)$ and neutral $(21,15 \%)$. "El País" articles offer the following vision on coexistence: positive $(32,3 \%)$, negative $(61,9 \%)$ and neutral $(5,8 \%)$.

The author also highlights some results from a survey about attitudes towards immigration carried out by the Spanish Sociological Research Center (Centro de Investigaciones Sociológicas, CIS) (CIS, 2009, cited in Llorent, 2012). Concerning the importance of some of the qualities required in foreigners to allow them to live in Spain, respondents indicated in first place that they should be willing to adopt the country's way of life. Concerning the source of 
information that shapes opinions about immigration to the greatest extent, respondents placed, first, their own experience and, second, news from the media. They also considered that the image of immigrants presented in the media is rather negative (46,3\%); $21 \%$ considered it positive (Llorent, 2012).

Given all this, we decided to observe attitudes towards immigrants among students of the Primary Education Degree - future primary school teachers- We supposed that, in general, we would confirm the opinion in Checa and Arjona (2011), whose study also indicates that young people present anti-immigrant sentiments that are more moderate, as do those with a higher level of education or income.

\section{CULTURAL STEREOTYPES AS OBSTACLES TO COEXISTENCE}

We devote this section to stereotypes because we believe that, in order to know how to deal with intercultural or multicultural education, the teacher should understand cultural stereotypes, the risks they imply, and their functions and mechanisms (Níkleva, 2012).

Stereotypes are a way of classifying and pigeon-holinge people, a way of labelling a group of people, sometimes without knowing even one representative of said group. Stereotypes are doubtlessly inexact. We usually adopt the image given to us by the media. There are stereotypes for nationalities, races, classes, groups, genders, occupations, etc. In our environment - education - as in all other environments in our society, there are certain prejudices towards immigrants that make coexistence difficult. This is why we consider it appropriate to know the functions of stereotypes, because they explain why stereotypes exist and how they work (Níkleva, 2012).

\section{Stereotype functions}

We refer to Sangrador García's (1981) four-group classification of functions: projection and displacement, justification of attitudes or behaviors towards the stereotyped group, cognitive economy and behavior predictability, and individual social identification and group integration.

\section{Function 1. Projection and displacement}

Projection and displacement are two ego defense mechanisms. The former consists of projecting desires and feelings considered socially unacceptable onto other groups. Displacement is explained by people's frustrations. Normally, these frustrations generate an aggressiveness that accumulates 
until people, needing to unload it, end up redirecting it towards a minority group that serves as a "scapegoat". This is how stereotypes emerge as manifestations of hostile attitudes and displaced aggression. Displacement is related to the scapegoat theory. The scapegoat is assigned the blame that would otherwise fall upon us.

\section{Function 2. Justification of attitudes or behaviors towards the stereotyped group}

We have already seen that stereotypes are used to justify hostile attitudes and behaviors and that they can come from displacement or real intergroup conflict. Thus they manage to maintain the existing social structure, an important effect of stereotypes. A negative stereotype justifies denying a minority or marginal group equal opportunity, certain benefits, etc. If members of this group are considered "lazy", denying them employment will seem "normal". If they are "not very intelligent", then there is no use in educating them. Self-fulfilling prophecies are based on this: inequality of treatment generates real inequality in time. In other words, with stereotypes, cause and effect are inverted. For example, if unemployment is the cause and laziness its effect - and that's why we see unemployed young people roaming the streets-a stereotype where the young are unemployed (effect) because they are lazy (cause) is eventually created. This cause and effect inversion in analyzing social reality is a way to deflect guilt: that is, we end up thinking less about the fact that the problem is unemployment and that unemployment is the responsibility of groups in power.

Another example of scapegoat-related discrimination is the hardworking ethnic group stereotype. In times of economic crisis and growing unemployment, many people lose their job and react emotionally, blaming the stereotyped hardworking group.

We stereotype groups that somehow represent a problem, a threat or a nuisance for the society we want to have. They may be related to a threat of war or a threat to the privileged position of dominant groups in the community. In summary, stereotypes reflect power relationships within society.

Finally, we must point out that stereotypes are not eternal. They are hard to change but they are not permanent. Stereotypes for different groups change with societal changes.

\section{Function 3. Cognitive economy and behavior predictability}

This is a double function formulated by authors of cognitive theory. These authors concentrate not on the demeaning connotations stereotypes 
normally have, but on their positive aspects, such as their capacity to make communication easy by simplifying environmental complexities. Stereotypes are part of a categorization process enabling the individual to predict his/her surroundings. This way, they act as a sort of model and save us time and analytical efforts. For example, if we find a stereotype group member, we tend to think he/she will have his/her group's basic stereotypical features and this assumption becomes the starting point for the interaction.

The authors who have established this double function conclude that reacting to every person and every event as if it were a single identity is neither possible nor convenient.

On the other hand, let's not forget that stereotypes are not the only forms offering this cognitive economy and behavioral predictability. Gestures, skin color, dress style, language registers, etc., have the same functions. In other words, nonverbal language and cultural and sociolinguistic features offer us the same type of information.

\section{Function 4. Individual social identification and group integration}

According to this function, individuals perceive themselves as members of certain groups in which some attitudes are accepted more or less officially. The individual identifies with these attitudes in his/her desire to be accepted by the group. For example, the integration of an individual in political, religious, etc. groups, requires accepting the group's predominant stereotypes, especially those referring to other political or religious groups.

One must remember that stereotyped groups may modify their own behavior as a result of the stereotyping. Thus an originally false stereotype may end up becoming true. In other words, due to the image people ascribe to a stereotyped group, this group's behavior may eventually match that image.

\section{RESEARCH OBJECTIVES AND HYPOTHESES}

In this study, we proposed the following objectives:

1) To identify predominant attitudes toward immigrants among future teachers.

2) To analyze the connotations of the words foreigner and immigrant.

3) To know which nationalities future teachers like the most and the least, and the reasons upon which they base their opinion. 
4) To see if their attitudes depend on whether they have had immigrant classmates.

5) To learn their opinion as to approach they might take as future teachers to integrate immigrant students and avoid racist attitudes.

In this study's initial stage, we formulated the following hypotheses:

1) Predominant attitudes towards immigrants are positive.

2) Positive connotations are created for the word foreigner, negative connotations are created for the word immigrant.

3) Future teachers prefer nationalities from developed countries and countries with similar culture or language.

4) The personal positive or negative experience of having had immigrant classmates correspondingly influences attitudes towards immigrants.

5) The principle of equality will prevail in the approach the future teachers will adopt to integrate immigrant students.

\section{METHODOLOGY}

Here we present the methodology used in this study: participants, research tools, and data analysis methods.

\section{Participants}

The participants in this research are made up of 151 first year students of the Primary Education Degree at the University of Granada, Faculty of Educational Sciences.

\section{Research instrument}

Table 1.

Mode, frequency and percentage for some answers

\begin{tabular}{l|c|c|c|c|c|c}
\hline \multicolumn{1}{c|}{ Questions } & Mode & $\mathbf{1}$ & $\mathbf{2}$ & $\mathbf{3}$ & $\mathbf{4}$ & $\mathbf{5}$ \\
\hline $\begin{array}{l}\text { Are there too many immigrants } \\
\text { in Spain? }\end{array}$ & 3 & $\begin{array}{c}16 \\
\text { In }\end{array}$ & $\begin{array}{c}9 \\
6\end{array}$ & $\begin{array}{c}51 \\
34 \%\end{array}$ & $\begin{array}{c}39 \\
26 \%\end{array}$ & $\begin{array}{c}35 \\
23.2 \%\end{array}$ \\
\hline $\begin{array}{l}\text { Would you like there to be fewer } \\
\text { immigrants? }\end{array}$ & 3 & 35 & 21 & 52 & 21 & 20 \\
\hline
\end{tabular}




\begin{tabular}{|c|c|c|c|c|c|c|}
\hline Questions & Mode & 1 & 2 & 3 & 4 & 5 \\
\hline $\begin{array}{l}\text { Would you like to teach only stu- } \\
\text { dents of Spanish origin during } \\
\text { your teaching practice, before } \\
\text { completing your degree? }\end{array}$ & 1 & $\begin{array}{c}52 \\
34.4 \%\end{array}$ & $\begin{array}{c}19 \\
12.6 \%\end{array}$ & $\begin{array}{c}48 \\
31.8 \%\end{array}$ & 17 & $\begin{array}{c}15 \\
9.9 \%\end{array}$ \\
\hline $\begin{array}{l}\text { Would you like to teach students } \\
\text { of Spanish origin and some } \\
\text { immigrants during your teaching } \\
\text { practice, before completing your } \\
\text { degree? }\end{array}$ & 5 & $\begin{array}{l}5 \\
3.3 \%\end{array}$ & $\begin{array}{l}7 \\
4.6 \%\end{array}$ & $\begin{array}{c}41 \\
27.2 \%\end{array}$ & $\begin{array}{c}31 \\
20.5 \%\end{array}$ & $\begin{array}{c}67 \\
44.4 \%\end{array}$ \\
\hline $\begin{array}{l}\text { Immigrants take away jobs from } \\
\text { Spanish people. }\end{array}$ & 3 & $\begin{array}{c}40 \\
26.7 \%\end{array}$ & $\begin{array}{l}22 \\
4.7 \%\end{array}$ & $\begin{array}{c}45 \\
30 \%\end{array}$ & $\begin{array}{c}30 \\
20 \%\end{array}$ & $\begin{array}{l}13 \\
8.7 \%\end{array}$ \\
\hline $\begin{array}{l}\text { Immigrant students take away } \\
\text { school places from Spanish } \\
\text { children. }\end{array}$ & 1 & $\begin{array}{c}49 \\
33.1 \%\end{array}$ & $\begin{array}{l}33 \\
2.3 \%\end{array}$ & $\begin{array}{c}43 \\
29.1 \%\end{array}$ & $\begin{array}{c}15 \\
10.1 \%\end{array}$ & $\begin{array}{l}8 \\
5.4 \%\end{array}$ \\
\hline $\begin{array}{l}\text { The presence of immigrant } \\
\text { students in a classroom reduces } \\
\text { academic performance for all } \\
\text { students. }\end{array}$ & 1 & $\begin{array}{c}55 \\
36.4 \%\end{array}$ & $\begin{array}{c}42 \\
27.8 \%\end{array}$ & $\begin{array}{c}36 \\
23.8 \%\end{array}$ & $\begin{array}{l}15 \\
9.9 \%\end{array}$ & $\begin{array}{c}3 \\
2 \%\end{array}$ \\
\hline $\begin{array}{l}\text { Would you like your children not } \\
\text { to have immigrant classmates in } \\
\text { their school? }\end{array}$ & 1 & $\begin{array}{l}105 \\
70 \%\end{array}$ & $\begin{array}{c}20 \\
13.3 \%\end{array}$ & $\begin{array}{c}22 \\
14.7 \%\end{array}$ & $\begin{array}{l}2 \\
1.3 \%\end{array}$ & $0.7 \%$ \\
\hline $\begin{array}{l}\text { Would you like your children not } \\
\text { to have immigrant friends? }\end{array}$ & 1 & $\begin{array}{c}107 \\
71.3 \% \\
\end{array}$ & $\begin{array}{c}15 \\
10 \% \\
\end{array}$ & $\begin{array}{c}23 \\
15.3 \% \\
\end{array}$ & $\begin{array}{c}4 \\
2.7 \% \\
\end{array}$ & $0.7 \%$ \\
\hline $\begin{array}{l}\text { Race influences student acade- } \\
\text { mic performance. }\end{array}$ & 1 & $\begin{array}{c}90 \\
60 \%\end{array}$ & $\begin{array}{c}19 \\
12.7 \%\end{array}$ & $\begin{array}{c}33 \\
22 \%\end{array}$ & $\begin{array}{c}6 \\
4 \%\end{array}$ & $\begin{array}{l}2 \\
1.3 \%\end{array}$ \\
\hline
\end{tabular}

Our research instrument is a 41 -item questionnaire with closedand open-ended questions. This questionnaire combines dichotomous and open questions with Likert scale questions asking students to specify their agreement or disagreement with statements through a 1 to 5 value scale (from least to most agreement). We do not attach the questionnaire for reasons of space but we quote and explain questions that we consider most relevant to the study.

\section{Analysis methods}

Data analysis was carried out with the SPSS 17.0 statistics software (Statistical Product and Service Solutions). Variables were subjected to descriptive analysis to obtain the frequency and percentages of the results. To study the relation between qualitative variables, we used cross tabs (inferen- 
tial analysis) and independent contrasts by means of chi-square statistics. Wherever significant contrasts were found, we measured the association strength Cramer's V.

\section{DATA ANALYSIS AND RESULTS DISCUSSION}

\section{Descriptive analysis results}

The age of participants varies between 18 and 51, with a median of 20.60 and a mode of 19 . Women make up the majority $(57.60 \%)$.

Concerning the descriptive analysis, we specify mode, frequency and percentage for some answers according to the Likert scale in Table 1.

These results confirm our hypothesis about how a lower age and a greater level of education determine lower rejection and higher empathy towards immigrants.

In a multiple-answer question we asked students to write the first five words that would come to mind when thinking about the word immigrant ( $2 \%$ didn't answer). They were not given a list of words. It was an open question. We then grouped the results into 20 categories, presented in Table 2. The poverty, hunger, need, etc. group dominates.

Table 2.

Results of words associated with immigrant, in descending order of frequency

\begin{tabular}{r|l|c|c|c}
\hline \multirow{2}{*}{$\mathbf{N}^{\circ}$} & \multicolumn{3}{|c}{ Word Category } & \multicolumn{3}{|c}{ Answers } \\
\cline { 3 - 5 } & & Number & $\%$ & $\%$ of cases \\
\hline 1 & Poverty, hunger, need, hard life, difficult & 247 & $36.1 \%$ & $166.9 \%$ \\
2 & Different culture and habits & 68 & $9.9 \%$ & $45.9 \%$ \\
3 & Foreigner (other nationality, other country) & 61 & $8.9 \%$ & $41.2 \%$ \\
4 & Color, race, black, Chinese & 57 & $8.3 \%$ & $38.5 \%$ \\
5 & Multiculturality, diversity, different, strange & 47 & $6.9 \%$ & $31.8 \%$ \\
6 & Work, workers & 36 & $5.3 \%$ & $24.3 \%$ \\
7 & Language, tongue & 33 & $4.8 \%$ & $22.3 \%$ \\
8 & Arab, Moroccan, North African & 23 & $3.4 \%$ & $15.5 \%$ \\
9 & Other or several & 20 & $2.9 \%$ & $13.5 \%$ \\
10 & Equality, rights & 15 & $2.2 \%$ & $10.1 \%$ \\
11 & Criminality, mafia, conflicts, fights & 13 & $1.9 \%$ & $8.8 \%$ \\
12 & Adaptation, integration & 12 & $1.8 \%$ & $8.1 \%$
\end{tabular}




\begin{tabular}{r|l|r|r|c}
\hline \multirow{2}{*}{$\mathbf{N .}^{-0}$ Word Category } & \multicolumn{3}{|c}{ Answers } \\
\cline { 3 - 5 } & & 11 & $1.6 \%$ & $7.4 \%$ \\
\hline 13 & Romanian & 7 & $1.0 \%$ & $4.7 \%$ \\
14 & Distrust, insecurity, fear, danger & 6 & $0.9 \%$ & $4.1 \%$ \\
15 & Foreigner (guiri), rich & 6 & $0.9 \%$ & $4.1 \%$ \\
15 & Illegal, papers, boat & 6 & $0.9 \%$ & $4.1 \%$ \\
15 & Latin American & 6 & $0.9 \%$ & $4.1 \%$ \\
15 & Discrimination & 5 & $0.7 \%$ & $3.4 \%$ \\
16 & School, education, ATAL (Temporary Linguis- & & & \\
& tic Adaptation Classroom (Aula Temporal de & & & \\
& Adaptación Lingüística) & 5 & $0.7 \%$ & $3.4 \%$ \\
& Prostitution & 684 & $100 \%$ & $462.2 \%$ \\
\hline
\end{tabular}

One of our previous hypotheses pointed to negative connotations for the word immigrant rather than the word foreigner. We have confirmed this hypothesis with the question What is the difference for you between the words foreigner and immigrant (when both live in Spain)? Notice how both words are presented as synonyms in the question. The question was open and later we grouped the answers by category. The results also show that students associate a foreigner's stay with legality and an immigrant's stay with illegality.

In descending order of frequency, the following concepts dominate in student definitions for the word foreigner:

1) Tourism, vacation: $56.4 \%$

2) Other nationality: $10.7 \%$

3) Legal nature of the stay: $7.1 \%$. Etc.

Definitions for the word immigrant point to:

1) Economic reasons: $32.8 \%$

2) Residents, settlement: $30.7 \%$

3) Illegal nature of the stay: $11.7 \%$. Etc.

To detect attitudes towards different nationalities, we presented two multiple-choice open questions in which students had to give the three immigrant nationalities they liked the most, the three immigrant nationalities they liked the least, and the reasons for their choice in both cases (15.9\% did not answer). Students were not given a list of nationalities. Later we organized the answers into 16 groups of nationality or geographic origin (Table 3). 
Table 3.

Most liked and least liked immigrant nationalities, in descending order of frequency

\begin{tabular}{|c|c|c|c|c|c|c|c|c|c|}
\hline \multirow[b]{2}{*}{ N. ${ }^{\circ}$} & \multicolumn{4}{|c|}{ Most Liked Nationalities } & \multirow[b]{2}{*}{ N. ${ }^{\circ}$} & \multicolumn{4}{|c|}{ Least Liked Nationalities } \\
\hline & Nationality & $\begin{array}{l}\text { Number } \\
\text { (Fre- } \\
\text { quency) }\end{array}$ & $\%$ & $\begin{array}{c}\% \text { of } \\
\text { cases }\end{array}$ & & Nationality & $\begin{array}{c}\text { Number } \\
\text { (Fre- } \\
\text { quency) }\end{array}$ & $\%$ & $\begin{array}{l}\% \text { of } \\
\text { cases }\end{array}$ \\
\hline 1 & Latin Americans & 76 & $19.1 \%$ & $55.5 \%$ & 1 & Romanians & 93 & $27.9 \%$ & $73.2 \%$ \\
\hline 2 & Italians & 60 & $15.1 \%$ & $43.8 \%$ & 2 & Arabs & 76 & $22.8 \%$ & $59.8 \%$ \\
\hline 3 & English & 50 & $12.6 \%$ & $36.5 \%$ & 3 & Latin Americans & 46 & $13.8 \%$ & $36.2 \%$ \\
\hline 4 & French & 40 & $10.1 \%$ & $29.2 \%$ & 4 & Chinese & 37 & $11.1 \%$ & $29.1 \%$ \\
\hline 5 & Americans (US) & 24 & $6.0 \%$ & $17.5 \%$ & 5 & Slavs & 23 & $6.9 \%$ & $18.1 \%$ \\
\hline 5 & Africans & 24 & $6.0 \%$ & $17.5 \%$ & 6 & French & 10 & $3.0 \%$ & $7.9 \%$ \\
\hline 6 & Slavs & 20 & $5.0 \%$ & $14.6 \%$ & 7 & Germans & 9 & $2.7 \%$ & $7.1 \%$ \\
\hline 6 & Chinese & 20 & $5.0 \%$ & $14.6 \%$ & 8 & Africans & 8 & $2.4 \%$ & $6.3 \%$ \\
\hline 7 & Germans & 19 & $4.8 \%$ & $13.9 \%$ & 9 & English & 6 & $1.8 \%$ & $4.7 \%$ \\
\hline 7 & Arabs & 19 & $4.8 \%$ & $13.9 \%$ & 9 & Turks & 6 & $1.8 \%$ & $4.7 \%$ \\
\hline 8 & Others & 18 & $4.5 \%$ & $13.1 \%$ & 10 & Others & 5 & $1.5 \%$ & $3.9 \%$ \\
\hline 9 & Northerners & 9 & $2.3 \%$ & $6.6 \%$ & 11 & Portuguese & 4 & $1.2 \%$ & $3.1 \%$ \\
\hline 10 & Japanese & 8 & $2.0 \%$ & $5.8 \%$ & 11 & Italians & 4 & $1.2 \%$ & $3.1 \%$ \\
\hline 11 & Portuguese & 6 & $1.5 \%$ & $4.4 \%$ & 12 & Japanese & 3 & $0.9 \%$ & $2.4 \%$ \\
\hline \multirow[t]{3}{*}{12} & Romanians & 4 & $1.0 \%$ & $2.9 \%$ & 13 & Americans (US) & 2 & $0.6 \%$ & $1.6 \%$ \\
\hline & & & & & 14 & Northerners & 1 & 0.3 & $0.8 \%$ \\
\hline & Total & 397 & $100.0 \%$ & $289.8 \%$ & & Total & 333 & $100.0 \%$ & $262.2 \%$ \\
\hline
\end{tabular}

It is somewhat striking that the same language or a similar culture favors the formation of positive attitudes (Latin Americans in the first place, Italians in the second), while Romanians and Arabs are first and second respectively in negative attitudes, and make up the largest immigrant populations with a different culture and language.

Among the reasons for the formation of these attitudes, the following results need to be highlighted: for positive attitudes, most influential are a positive personal experience, culture and habits, similarity with Spaniards, an interest in languages, knowing the other country, and a sociable personality. Some respondents point out climate, food, even the talent for dancing, etc. as reasons for their opinion. Negative attitudes, on the other hand, are due to conflictive or criminal behavior, culture and habits (especially discrimination against women in Arab cultures), negative personal experience, etc. (Serradell \& Munté, 2010).

Assuming that having immigrant classmates and how they liked the experience influences students attitudes, we asked questions about this and 
the results indicate that $64.9 \%$ have had "few or some" immigrant classmates, $23.8 \%$ "many," and $11.3 \%$ "none". 52.6\% have liked the experience "quite a lot", 30.7\% "a lot," 15.3\% "not much" and 1.5\% "not at all". We also have to consider that $84.2 \%$ have studied in public schools and live in towns or cities with "quite a lot" (30.84\%), "many" (33.1\%) and few $(27.2 \%)$ immigrants. Only $1.3 \%$ answer that there are no immigrants where they live. The prevailing opinion of immigrants where they live is "bad/middling" $(61.6 \%)$, "good" $(23.2 \%)$, etc.

The reasons for positively or negatively valuing the experience of having immigrant classmates are, in the first place, cultural enrichment $(60.8 \%) ; 11.2 \%$ value being well treated; while only $1.3 \%$ considers that immigrants slow down classroom pace and worsen performance.

In our study it was important to know whether future teachers knew the two approaches to immigrant student treatment: inclusiveness (in the mainstream classroom, as recommended by current legal policy) and segregation (temporarily outside the mainstream classroom until sufficient competence in linguistic communication in the vehicular language has been acquired). There are many studies that have contrasted the two approaches and concluded that the inclusive approach provides multiple advantages, better academic performance for all-not only foreign-students, and benefits to autochthonous students in learning curricular content in all areas (Barrios \& Morales, 2012).

In our study we wanted to know the preferences of the future teachers with respect to these two approaches. The results were very similar: $50.7 \%$ would choose a segregationist approach, while 49.3 would apply an inclusive approach (3.3\% did not answer).

The last question was open: How would you behave as a future teacher to integrate immigrant students in your group and avoid racist attitudes among students? The following principles and measures stood out: equality without discrimination, integration, interaction and respect, cooperation and group work, support classrooms and later integration, sports, movies, etc. Many students highlighted the importance of knowing immigrant cultures and the positive effects witnessed when experiencing this strategy in previous educational levels.

\section{Inferential analysis results}

To study interdependence between variables, we applied inferential analysis. The following stand out from among the results: 
The desire to have fewer immigrants depends on the source of information that has greatest influence on the formation of attitudes: $x^{2}(16)=$ 267.955, p '.05. Cramer's V indicated low dependence (.236). However, there is no dependence with the prevailing opinion on immigrants from where students come. In other words, the attitude of our students toward immigrants depends on the family, not on the opinion prevalent in the place they live. The descriptive analysis confirmed that the sources of information participating in molding attitudes toward immigrants are, in descending order, as follows: family $(35.7 \%)$, television $(31.7 \%)$, friends $(27.8 \%)$, the Internet $(4 \%)$, and news in print $(0.8 \%)$.

The experience of having had an immigrant classmate favors the desire to teach immigrants during teaching practices: $x^{2}(8)=67.093$, p '.05; Fisher's Exact Test $F=.002$. There's a medium dependence relationship (Cramer's V $=.404)$.

\section{CONCLUSIONS}

We have diagnosed the current situation concerning the attitudes of future teachers toward immigrants. This will help us design teaching intervention actions directed at improving the acceptance of the principles of inclusive education among future teachers. Our study confirms that young and more educated respondents have more empathy, less rejection and less xenophobia. However, we have also confirmed that attitudes and cultural stereotypes about the largest foreign nationalities in our society are being spread through the media.

The word immigrant is associated in the first place with poverty, need and an illegal stay. The word foreigner is attributed to a person with money who resides legally in Spain for pleasure.

Considering that stereotypes and prejudices hamper coexistence and are consolidated through a lack of intergroup contact - and therefore through a lack of knowledge of the Other-it becomes important to support these contacts in the educational sphere to improve attitudes towards immigrants and reduce xenophobia.

We would like to finish with an idea from Todorov, winner of the Social Sciences Prince of Asturias Award in 2008 (2007, p. 433): "[The individual] does not confuse love with justice: He loves his son more than his neighbor, but when both are together in his home, he gives them equal portions of the cake". Let's take these words to the classroom and reflect upon them together with our students. 


\section{REFERENCES}

Barrios, M. E. \& Morales, L. (2012). Apoyo lingüístico inclusivo a alumnado no hispanohablante y aprendizaje de competencias curriculares en Educación Primaria. Porta Linguarum, 17, 203-221.

Briones, E., Tabernero, C. y Arenas, A. (2011). Satisfacción de adolescentes autóctonos e inmigrantes con el país de residencia. Influencia de variables psicosociales relativas al contacto intergrupal. Cultura y Educación, 23(3), 341-354. doi: 10.1174/113564011797330315

Checa, C. J. y Arjona, A. (2011). Españoles ante la inmigración: El papel de los medios de comunicación. Comunicar, 37, 141-149. doi: 10.3916/C37-2011-0306

García, A. y Saura, J. (2008). Estudio de las consecuencias de la diversidad cultural en espacios de encuentro pluricultural. RESLA (Revista Española de Lingüística Aplicada), 21, 71-84.

Instituto de Formación de Profesorado, Investigación e Innovación Educativa (IFIIE) (2012). Evolución y situación actual de la presencia del alumnado extranjero en el sistema educativo español (2000-2011).
Instituto Nacional de Estadística (2012). Cifras oficiales de población resultantes de la revisión del Padrón municipal a 1 de enero de 2010. Retrieved from http:// goo.gl/Zk6Iv

Llorent, V. (2012). The Educational Role of the Digital Media in the Integration of Immigrants in Spain: elmundo.es and elpais.com. Comunicar, 38, 139146. doi: 10.3916/C38-2012-03-05

Níkleva, D. G. (2012). Educación para la convivencia intercultural. Árbor, 188(757), 991-999. doi: 10.3989/ arbor.2012.757n5013

Sangrador, J. L. (1981). Estereotipos de las nacionalidades y regiones de España. Madrid: Centro de Investigaciones Sociológicas.

Serradell, O. y Munté, A. (2010). Dialogicidad y poder en el discurso racista y antirracista. Revista Signos, 43 (suppl. 2), 343-362. doi: 10.4067/ S0718-09342010000400006.

Todd, E. (1996). El destino de los inmigrantes. Barcelona: Tusquets.

Todorov, T. (2007). Nosotros y los otros. Reflexión sobre la diversidad humana. Madrid: Siglo Veintiuno Editores. 


\section{PERFIL ACADÉMICO Y PROFESIONAL DE LAS AUTORAS}

Dimitrinka G. Níkleva. Profesora contratada doctora en el departamento de Didáctica de la Lengua y la Literatura, Facultad de Ciencias de la Educación, Universidad de Granada. Líneas de investigación: didáctica del español como lengua materna, segunda y extranjera; interculturalidad; español para inmigrantes; comunicación no verbal, pragmática, etc.

Ana M. Rico-Martín. Profesora Titular de Universidad en el departamento de Didáctica de la Lengua y la Literatura en la Facultad de Educación y Humanidades de Melilla, Universidad de Granada. Líneas de investigación: plurilingüismo, enseñanza bilingüe y adquisición de segundas lenguas, especialmente español-L2/LE, y la formación de maestros en contextos multiculturales. Pertenece al Grupo de Investigación del PAIDI "Innovación curricular en contextos multiculturales" (HUM-358).

Dirección de las autoras: Dimitrinka Georgíeva Níkleva

Facultad de Ciencias de la Educación

Campus Universitario de Cartuja, s/n

18071 Granada (España)

E-mail: nikleva@ugr.es

Ana M. ${ }^{a}$ Rico Martín

Facultad de Educación y Humanidades

C/ Santander, n. ${ }^{\circ} 1$

52071 Melilla (España)

E-mail: amrico@ugr.es

Fecha Recepción del Artículo: 13. Enero. 2014

Fecha Aceptación del Artículo: 27. Mayo. 2014

Fecha Revisión para Publicación: 06. Julio. 2016 
